4. 1972. Prime aux travailleurs du monde polaire. In: W. P. Adams and F. Helleiner (eds), International Geography 1972 (Papers submitted to the 22nd International Geographical Congress, Montreal), University of Toronto Press, 1: 381-84.

5Buck, W. K. and J. F. Henderson. 1965. The role of mineral resources in the development and colonization of northern Canada. In: W. V. Bladen, (ed) Canadian population and northern colonization, University of Toronto Press, p. 106.

6Dubnie, A. and W. K. Buck. 1965. Progress of mineral development in northern Canada. Polar Record, 12 (81): 701.

7Rea, K. J. 1968. The political economy of the Canadian North. University of Toronto Press, p. 187.

8Wolforth, J. 1971. The evolution and economy of the Delta Community. Northern Science Research Group, Department of Indian Affairs and Northern Development, Ottawa (Mackenzie Delta Research Project no. 11), pp. 118-20.

9Northwest Territories. 1971. Teach in Canada's Arctic. Northwest Territories. Department of Education, Yellowknife, $36 \mathrm{pp}$.

10Parsons, G. F. 1970. Arctic suburb: a look at the North's newcomers. Northern Science Research Group, Department of Indian Affairs and Northern Development, Ottawa, p. 17.

11Jenness, D. 1964. Eskimo administration: II. Canada. Arctic Institute of North America, Technical Paper no. 14, p. 129.

12Brant, C. S. and C. W. Hobart. 1968. The educational system in the Western Arctic. In: Valentine, V. F. and F. G. Vallee (eds). Eskimo of the Canadian Arctic. Toronto: McClelland and Stewart (Carleton Library no. 41), p. 187.

13McCourt, E. 1969. The Yukon and Northwest Territories. Toronto: Macmillan, p. 211.

14Phillipps, R. A. J. 1967. Canada's North. Toronto: Macmillan, p. 240.

\section{Polar Bear Predation on Beluga in the Canadian Arctic}

During May 1970, while conducting field work at Grise Fiord in the Canadian Arctic Archipelago, a local hunter reported that a polar bear (Ursus maritimus) had successfully caught 3 beluga (Delphinapterus leucas) during March near King Edward VII Point $\left(76^{\circ} 08^{\prime}\right.$ N., $81^{\circ} 08^{\prime} \mathrm{W}$.), the extreme southeast cape of
Ellesmere Island, Northwest Territories. As none of the fifteen local hunters had ever witnessed such an event, and only one had ever heard of it before, I assumed bear predation on whales to be very rare, and consequently recorded whatever information I could obtain at the time.

According to the hunter's narrative, movement of a partially grounded iceberg about 200 metres offshore had prevented freezing of a small area of water surrounding the berg. Winter trapment of whales is known to occur during unusual conditions of sea-ice formation 1 , and as the open sea was at least 30 kilometres distant from this locality in March it seems probable that a small number of beluga had endeavoured to pass the winter in the open water alongside this berg. At some time in March a medium-sized female bear had caught and removed an adult female beluga together with another adult and a grey-coloured subadult beluga both of unspecified sex; the adult female beluga was dragged about 7 metres from the edge of the water, the other two a shorter distance only.

On 25 May an attempt was made to visit this Jocation, but when within about 15 kilometres the tracks of a large male bear were seen, and hunting this animal took up the remainder of the day. The stomach of this 400-kilogram bear contained, in addition to some skin and fat of a newly-killed ringed seal (Pusa hispida), several pieces of white beluga skin.

Four days later on reaching the site of the whale kill, only the carcass of the grey beluga remained; apparently movement of the berg had broken up the ice and no trace of the other two carcasses could be found. The remaining carcass was attracting large numbers of glaucous gulls (Larus hyperboreus) and some ravens (Corvus corax) and earlier that day two male bears had been present. The smaller of the two bears had walked backwards dragging the beluga carcass tail-first in a zig-zag course a distance of about $\mathbf{1 5 0}$ metres from an earlier resting place on the ice.

Inspection of the carcass indicated loss of all skin and fat, and most of the meat from head and trunk; fracture of the occipital bones had occurred, but it is not known if this damage was suffered before or after death. An eyewitness account of a polar bear killing beluga in Novaya Zemblya however, relates how the bear lies with outstretched paws on the ice and delivers a blow to the head when the whale surfaces within range 2 .

In this region of the Canadian Arctic Archipelago, beluga generally change colour from grey to white at around $375 \mathrm{~cm}$. in length. 3 Assuming the two white-coloured 
beluga were around $400 \mathrm{~cm}$. in length, their weight is calculated to be about 935 kilograms ${ }^{4}$; the grey-coloured sub-adult measured $275 \mathrm{~cm}$. and had a computed weight of 350 kilograms.

There appears no reason to doubt that the hunter reporting this event had, as he believed, discovered the beluga shortly after they were caught in March, nor that the tracks of the medium-sized female bear near the carcasses at that time were those of the predator. According to the description given, such a bear would weigh in the range of 130 to 180 kilograms, or about one-fifth the probable weight of each adult beluga it had successfully killed and removed from the water.

The only other reports on bears killing beluga $I$ can find in the literature appear contradictory. One asserts that, in the Baffin Bay region, at small openings in the ice where whales are sometimes trapped in winter, "a small flock of bears will congregate and kill a small whale, which they will then drag up on to the ice and eat"5. The other commentary, relating to the Eurasian arctic, suggests that attacks on beluga by single bears are quite frequent, and that when a bear discovers a pod of trapped whales it remains nearby and successively kills them (up to 13 are reliably reported2).

This present report of a multiple killing by a solitary bear, substantiated by direct inspection shortly after the event, establishes that there is no difference between Eurasian and North American polar bears in regard to this predatory behaviour.

\section{Milton M. R. Freeman}

Department of Sociology and Anthropology McMaster University

Hamilton, Ontario

\section{REFERENCES}

1Freeman, M. M. R. 1968. Winter observations on beluga (Delphinapterus leucas) in Jones Sound, N.W.T. Canadian Field-Naturalist, 82:276-86.

2Kleinenberg, S. E., A. V. Yablokov, B. M. Bel'kovich and M. N. Tarasevich. 1964. Beluga (Delphinapterus leucas): Investigation of the species. Israel Program for Scientific Translations Ltd. p. 292.

3Field notes, 1965-66. Unpublished.

4Sergeant, D. E. and P. F. Brodie. 1969. Body size of white whales, Delphinapterus leucas. Journal of the Fisheries Research Board of Canada, 26:2561-80.

5Degerb $\phi 1$, M. and P. Freuchen. 1935. Mammals. Report of the Fifth Thule Expedition, 2 (4-5):109.

\section{Mammal and Bird Names in the Indian Languages of the Lake Athabasca Area}

When Lake Athabasca first became known to white men in the eighteenth century, the area to the south and west of the lake was inhabited by Beaver Indians, part of the north shore and the Slave River area belonged to the Slave Indian domain, whereas Chipewyans lived about the eastern extremity of the lake. These three tribes belong to the larger Athapaskan or Dené group of people which, in the aggregate, occupied all of what is now western Canada from the land of the Eskimos south to that which was then controlled by the Crees and related Algonkian tribes such as the Blackfoot, Blood and Piegans $(1: 378)$.

The Beaver Indians were driven out of the Lake Athabasca area before 1760 by Cree bands who had obtained firearms from fur traders on Hudson Bay. The eastern Beaver, after making peace with the Cree, traded at Fort Chipewyan for a short period, but gave up the Athabasca portion of their former range when fur trading posts were established on the Peace River $(1: 383)$. The Cree invasion which expelled the Beaver Indians from part of their earlier range, also drove out the closely related Slaves (this was not what they called themselves) of the Lake Athabasca area. About 1725 , the Cree area in this region had extended northward along the Athabasca River valley only to a point somewhat south of McMurray. War with the Beavers, Slaves and Chipewyans carried a number of Cree bands north as far as Lake Athabasca and beyond down the Slave River valley to the south shore of Great Slave Lake. In 1760, the Crees and Chipewyans made peace and became the sole native inhabitants of the region. Crees naturally predominate in the western and Chipewyans in the eastern part of the area.

Our word "Chipewyan" derives from the Cree name "witshipeean" for their Athapaskan neighbours; it means "pointed skins", referring either to the form in which they dried their beaver skins, or the shape of their original skin shirt tails which were pointed, like those of the Eskimo, before and behind $(1: 385)$. The word "Chipewyan" must not be confused, as is sometimes done in newspapers, with "Chippewa" (Chippewan as an adjective), a synonym of "Ojibwa", both names for the eastern and equally Algonkian, closely related neighbours of the Crees. The Chipewyans, like the Athapaskans generally and the Eskimos, simply called themselves the people: "dené" in their own language. 